\title{
An assessment of subsoil organic carbon stocks in England and Wales
}

\author{
A. S. Gregory ${ }^{1}$, G. J. D. Kirk ${ }^{2}$, C. A. KeAY $^{2}$, B. G. RAWlins ${ }^{3}$, P. WAllace ${ }^{4}$ \& A. P. Whitmore ${ }^{1}$ \\ ${ }^{1}$ Department of Sustainable Soils and Grassland Systems, Rothamsted Research, Harpenden, Hertfordshire \\ AL5 $2 J Q, U K$ \\ ${ }^{2}$ National Soil Resources Institute, Cranfield University, Cranfield, Bedfordshire MK43 0AL, UK \\ ${ }^{3}$ British Geological Survey, Keyworth, Nottingham NG12 5GG, UK \\ ${ }^{4}$ Phil Wallace Ltd, Ipswich, Suffolk, UK
}

Correspondence: A. S. Gregory. E-mail: andy.gregory@rothamsted.ac.uk

\begin{abstract}
It is estimated that half the soil carbon globally is in the subsoil, but data are scarce. We update estimates of subsoil organic carbon (OC) in England and Wales made by Bradley et al. (2005; Soil Use Manage. 21, 363369) using soil and land use databases, and compare the results with other published data. We estimate that the soils of England and Wales contain 11406, 980 and $433 \mathrm{Tg}$ of OC at 0-30, 30-100 and 100-150 cm depths, respectively. Thus half of the soil OC is found below $30 \mathrm{~cm}$ depth. Peat soils account for the largest proportion, containing $44 \%$ of all the OC below $30 \mathrm{~cm}$ despite their small areal extent, followed by brown soils, surface-water gley soils, ground-water gley soils, and podzolic soils. Peat soils have more than $25 \%$ of their profile OC per unit area in the 100-150 cm depth, whereas most other soils have less than $8 \%$ at this depth. The differences between soil types are consistent with differences in soil formation processes. Differences in depth distributions between land uses are small, but subsoil OC stocks in cultivated soils are generally smaller than in soils under grassland or other land uses. Data on subsoil OC stocks in the literature are scarce, but what there is broadly agrees with the findings of the above database exercise. There is little evidence with which to assess how subsoil OC stocks are changing over time.
\end{abstract}

Keywords: Soil type, land use, land use change, databases, literature review, monitoring

\section{Introduction}

It is estimated that over half the soil organic carbon (OC) globally is stored in the subsoil below $15-30 \mathrm{~cm}$ depth (Batjes, 1996; Jobbágy \& Jackson, 2000). However our knowledge and understanding of soil OC is largely restricted to the topsoil, most research having been done there because it is more-readily accessible and most obviously influenced by the inputs and losses of $\mathrm{C}$ as they interact with the environment (King et al., 2005). National soil monitoring schemes generally assess just the upper 15 to $30 \mathrm{~cm}$ of the profile (Bellamy et al., 2005; Emmett et al., 2010). The effects of soil type, climate, management and other drivers on subsoil OC are largely unknown (Harrison et al., 2011; Poeplau et al., 2011; Rumpel \& Kögel-Knabner, 2011; Schmidt et al., 2011). The reasons for this neglect include the time-consuming and arduous task of sampling subsoil, and the traditional view that subsoil OC is stable. However there is increasing interest in the nature and properties of subsoil OC and its importance in the global C cycle (e.g. Jenkinson et al., 2008; Chabbi et al., 2009; Rumpel \& Kögel-Knabner, 2011; Schmidt et al., 2011).

In this paper we estimate stocks of subsoil OC in England and Wales using existing spatial databases on soils and land use, building on the work of Bradley et al. (2005). We also review other published information on subsoil OC stocks in England and Wales, focussing on the effects of soil type and land use.

\section{Methodology}

\section{Database exercise}

In outline, we obtained the spatial distribution of soil types and land uses across England and Wales by overlaying the 1:100 000 Countryside Survey Land Cover Map for 1990 (LCM; Fuller et al., 1993) on the 
1:250 000 National Soil Map (NATMAP; Mackney et al., 1983), and finding the area of each soil seriesland use combination in $1 \mathrm{~km}$ grid squares. We then obtained data on soil properties down the soil profile for each of the soil series-land use combinations from data held in the LandIS database (www.landis.org.uk; Proctor et al., 1998). We followed broadly the same approach as Bradley et al. (2005) except we used a different method to combine the data on soil type and land use (see below) and we included data to $150 \mathrm{~cm}$ depth whereas Bradley et al. used only data to $100 \mathrm{~cm}$. Note that not all soils in England and Wales are $150 \mathrm{~cm}$ deep and some are deeper. The details are as follows.

Spatial distribution of soil types and land use. The NATMAP, created by Soil Survey of England and Wales (SSEW), gives the distribution of 296 soil associations, each comprising between one and eight soil series found together in particular landscapes. We created a soil series dataset at $1 \mathrm{~km}$ resolution from the NATMAP by integrating the fraction of each soil association in each $1 \mathrm{~km}$ square with the fraction of all the soil series in each soil association. To determine the soil series-land use combinations in each square, we obtained the fraction of each land use in each square using the LCM, and then multiplied the coverage of the soil series by the coverage of the land use. This contrasted with the approach of Bradley et al. (2005) who combined the soil and land use data according to eight sets of rules (combining either the dominant or each land use type in each square with the dominant or each of up to five soil types, soil type having been defined by combining soil series at the sub-group level) and taking the average result across the eight. We used the three land use categories specified in the LandIS database: cultivated land (mainly arable but also rotational grassland); permanent managed grassland; and 'other' (including unmanaged grassland, semi-natural vegetation and woodland).

Soil profile data. We extracted soil OC content, stoniness and bulk density data from the Horizon Fundamentals dataset in LandIS for each soil series-land use combination identified above. The Horizon Fundamentals dataset was created with data from 1289 soil profiles sampled to characterise soil series during detailed field survey in the SSEW (Hallett et al., 1995). For the majority of soil series, multiple datasets are available and mean parameter values were calculated. The topsoil $(0-15 \mathrm{~cm})$ OC data obtained from the profiles was augmented by data from the National Soil Inventory (Bellamy et al., 2005), stratified by soil series and land use. Soil sampling and laboratory analyses followed standard SSEW procedures (Avery \& Bascomb, 1982), with soil OC measured by the modified Walkley-Black method (Nelson \& Sommers, 1996) on the fine earth fraction $(<2 \mathrm{~mm})$. Litter horizons were excluded. The above mapping exercise identified 434 soil series. In cases where the mapping exercise produced a soil series-land use combination for which there was no Horizon Fundamentals data, indicating that this series-land use combination should not occur (this affected 17,7 and $3 \%$ of the soil series under cultivated land, grassland and other, respectively), we populated the dataset with data from the most-similar land use: for cultivated land we used grassland data firstly or, if that did not exist, data for other; for grassland, firstly with other and then cultivated land; and for other, firstly with grassland and then cultivated land.

Soil OC stocks. We calculated the soil OC stock per unit area in each depth interval for each soil series-land use combination identified above from:

$C_{i}=\hat{C}_{i}\left(1-S_{i}\right) \Delta z_{i} \rho_{i}$

where $C$ is the OC stock per unit area $\left(\mathrm{g} \mathrm{m}^{-2}\right), \hat{C}$ is the OC content per unit mass $\left(\mathrm{g} \mathrm{kg}^{-1}\right.$, determined on the $<$ $2 \mathrm{~mm}$ fraction), $S$ is the stoniness ( $\mathrm{kg} \mathrm{kg}^{-1}$, the $>2 \mathrm{~mm}$ fraction), $\Delta z$ is the soil depth increment ( $\left.\mathrm{m}\right), \rho$ is the bulk density $\left(\mathrm{kg} \mathrm{m}^{-3}\right)$, and subscript $i$ indicates the $i$ th depth. We calculated OC stock values for depth intervals $0-30,30-100$ and $100-150 \mathrm{~cm}$ by summing the values for individual horizons. Where horizons straddled a boundary between depth intervals, the data were apportioned between the depths pro rata. For each of the three depth intervals we calculated weighted mean OC stocks per unit area for soils classified by their Major Soil Groups distinguished by the SSEW (Table 1) under each land use: 


$$
\bar{C}=\frac{\sum_{j=1}^{n}\left(w_{j} C_{j}\right)}{\sum_{j=1}^{n} w_{j}}
$$

where $\bar{C}$ is the weighted OC stock per unit area, and $C_{j}$ and $w_{j}$ are the OC stock per unit area and its weighting, respectively, for the $j$ th soil series, and:

$$
w_{j}=\frac{A_{j}}{\sum_{j=1}^{n} A_{j}}
$$

where $A_{j}$ is the area of the $j$ th series $\left(\mathrm{km}^{2}\right)$. The standard deviation of the mean is then:

$\sigma_{i}=d \sqrt{\sum_{j=1}^{n} w_{j}^{2}}$

where $d$ is the standard deviation of the set of $C_{j}$ values, assuming they are equal. The total soil OC stock for each Major Soil Group and land use combination in England and Wales is then given by multiplying the stock per unit area by the total area occupied by the combination.

\section{Literature review}

A literature review on subsoil OC stocks in England and Wales was conducted largely through the webbased ISI Web of Knowledge ${ }^{\text {SM }}$ search engine (Thomson Reuter, New York, USA). Where given, we reported principal site and soil attributes, and the OC stock by depth. We list the soil type by both the SSEW Major Soil Group (Table 1) and the Reference Soil Group of the UN Food and Agriculture Organisation World Reference Base (WRB) system (IUSS-ISRIC-FAO, 2006). We used the same OC stock units, land use and depth categories and methods as above, except for uncultivated soils where, if reported, the $0-30 \mathrm{~cm}$ depth was split into separate $0-15$ and $15-30 \mathrm{~cm}$ intervals to reflect the particular horizonation of such soils. Where the deepest depth interval in the literature failed to attain the lower depth of a standard depth interval, our criteria was to extrapolate a given OC stock for the remainder of the corresponding depth interval only if the lower depth given was closer to the standard interval lower depth than the upper depth. In other words, extrapolation of a stock down to 100 or $150 \mathrm{~cm}$ depth was only done if the literature reported the stock down to at least 65 or $125 \mathrm{~cm}$, respectively.

Where there were data on OC stocks at a particular site over time, we calculated mean annual changes by dividing the change between measurements by the sampling interval. This assumes the change is linear. This is realistic for intervals of a decade or so under established land management (Bellamy et al., 2005). For longer periods, or following changes in land management, this may be erroneous and the results should be treated with caution.

\section{Results and Discussion}

\section{Subsoil OC stocks per unit area}

Figure 1 shows the OC stocks per unit area obtained from the database exercise for individual soil series by land use. The distributions show a good deal of scatter, reflecting differences between soil types (see below) and locations. We attempted to fit exponential (pace Bernoux et al., 1998) and spline (pace Malone et al. 2011; Odgers et al., 2012) curves to the data, but the fits were poor, and there were insufficient data to fit 
curves for individual soil types. We therefore analysed the data by specified depth intervals (cf Jobbágy \& Jackson, 2000; Goidts \& Wesemael, 2007; Saby et al., 2008; Wiesmeier et al., 2012).

Table 2 shows the weighted-mean values of soil OC per unit area by depth for the different soil types and land uses. The differences between land uses in the proportions at different depths are small, though there are clear differences in the total stocks, which increase in the order cultivated land to grassland to other. These reflect, in part, difference in plant inputs of $\mathrm{C}$ and the intensiveness of soil disturbances due to management. The depth-distributions reflect past land uses as well as the effects of current managements. For example, much of the subsoil OC under cultivated land is likely to be from former grassland. Based on isotopic signatures, subsoil OC is often much older than topsoil OC (Jenkinson et al., 2008).

Peat soils have the largest subsoil OC stocks per unit area, followed by gley soils and podzolic soils, and then pelosols. Peat can contain more than 200 times as much OC as the overlying vegetation (Garnett et al., 2001). Lithomorphic and man-made soils have the smallest total OC stocks per unit area and more than 90 $\%$ of this is at $0-30 \mathrm{~cm}$ depth. Most soils have $50-60 \%$ of their OC at $0-30 \mathrm{~cm}$ depth, except peat soils which have only $20 \%$, with about $30 \%$ at $100-150 \mathrm{~cm}$ depth. Gley soils and pelosols have $12-17 \%$ of their OC at 100-150 cm depth whilst others have less than $8 \%$.

These results are consistent with the processes of soil formation in different soils. Large subsoil OC stocks in periodically waterlogged gley soils reflect impaired decomposition of organic matter under anoxic conditions as well as illuviation of dissolved and particulate OC from upper horizons. Illuviation of OC chelated with metals also accounts for elevated subsoil OC in podzolic soils. Surface-water gley soils have somewhat larger proportions of their OC in the topsoil than ground-water gley soils, presumably reflecting their different hydrologies. The large stocks at depth in pelosols reflect their vertic properties and resulting seasonal shrinkage and deep cracking which cause topsoil organic matter to be incorporated to depth.

\section{Total subsoil OC stocks}

Table 3 shows the total OC stocks for the two countries subdivided by soil type and land use. Cultivated soils have smaller OC stocks at 30-150 cm depth (348 Tg) than soils under grassland (429 $\mathrm{Tg}$ ) and other land uses $(636 \mathrm{Tg})$. For cultivated land, the order from greatest to smallest stock at $30-150 \mathrm{~cm}$ depth is brown soils $\approx$ peat soils $>$ surface- and ground-water gley soils $>$ pelosols; for grassland it is brown soils $>$ surface-water gley soils $>$ peat soils $>$ ground-water gley soils $>$ podzolic soils; and for other land uses it is peat soils $>>$ surface-water gley soils $>$ brown soils $>$ podzolic soils. The overall order across all land uses is peat soils $>>$ brown soils $\approx$ surface-water gley soils $>$ ground-water gley soils $>$ podzolic soils $\approx$ pelosols.

The results reflect the differences in stock per unit area and the areal extents of the soils. Peat soils are the most important stores of OC in England and Wales overall, containing $44 \%$ of all the soil OC present below $30 \mathrm{~cm}$, in spite of their small extent (4\% of the total land area). By contrast, brown soils have the greatest areal extent (39\% of the total area) but have only small OC contents per unit area. These soils are heavily used for cultivated agriculture in England and Wales.

The estimated total OC stocks in England and Wales for the 0-30 and 30-100 cm depths are 1633 and 1143 Tg, respectively, which compares with 1209 and $870 \mathrm{Tg}$, respectively, reported by Bradley et al. (2005), i.e. our estimates are 35 and $31 \%$ greater, respectively. The differences are due to the methodological differences outlined above. The differences are greater in the other land use (79 and 36\% more at 0-30 and $30-100 \mathrm{~cm}$ depths, respectively) than in cultivated land (16 and $22 \%$, respectively) and grassland (23 and $33 \%$, respectively). A possible explanation is that the most abundant soils have below average OC contents, so that Bradley et al.'s method of combining soil and land use data by averaging results obtained with the most abundant soil type in each $1 \mathrm{~km}$ square with results obtained for the five most abundant soil types(see Spatial distribution of soil types and land use), leads to under-estimation of stocks. This is more evident in the other land use category because the soils are more varied. 
Nonetheless we agree with Bradley et al. (2005) that around $40 \%$ of soil OC in the top $100 \mathrm{~cm}$ of the profile is at depths greater than $30 \mathrm{~cm}$. We estimate there to be a further $506 \mathrm{Tg}$ of OC at $100-150 \mathrm{~cm}$ depths $(15 \%$ of the $0-150 \mathrm{~cm}$ stock). This gives an improved total OC stock estimate of $3822 \mathrm{Tg}$ in the upper $150 \mathrm{~cm}$ of the soils in England and Wales, of which half $(1919 \mathrm{Tg})$ is below $30 \mathrm{~cm}$.

\section{Subsoil OC stocks per unit area from the literature}

We found very little data on subsoil OC stocks in England and Wales in the literature review, and not all soil types were covered. With the exception of Bradley et al. (2005), we found only eight studies giving depthdistributions of $\mathrm{OC}$ with less than 50 soil profiles described (the database exercise above included more than 1300 profiles). We found several other sources of gravimetric subsoil OC data in England and Wales, but with no bulk density measurements from which to calculate stocks. The full dataset is given in Supplementary Information SI 1 and a summary is given in Table 4.

In general OC stocks reported in the literature were comparable to those in the database exercise, with 20 of the depth horizons reported in Table 4 having a stock within three standard deviations of the mean stock reported in Table 2 for the corresponding soil type and land use. Stocks tended to increase from cultivated land to grassland to other land uses, particularly within the same soil type (Ellis \& Atherton, 2003; Jenkinson et al., 2008). Inevitably there were some local differences due to site-specific effects. Greaterthan-average OC stocks were recorded for $\mathrm{N}$-fertilised grassland soils at Palace Leas (Hopkins et al., 2009), soils converted from cultivated to coarse grass and woodland at Rothamsted (Poulton et al., 2003), alluvial soil under cultivation at Shelford (Tye, 2010), and some reclaimed estuarine soils at Sunk Island (Ellis \& Atherton, 2003).

Some studies reported the effects of management within the same land use. Hopkins et al. (2009) found considerably more $\mathrm{OC}$ at $0-15 \mathrm{~cm}$ but less at $15-30 \mathrm{~cm}$ depth under $\mathrm{N}$-fertilised grassland than grassland not receiving $\mathrm{N}$ fertiliser at Palace Leas. This may reflect increased plant growth and, hence, increased inputs with $\mathrm{N}$ addition. Wilson et al. (1997) found that OC stocks at $15-30 \mathrm{~cm}$ depth under ancient woodland were greater in brown soil at two sites compared to more recent plantations, but lesser in a podzolic soil at a third site. At Rothamsted there was more OC under regenerating woodland on a neutral-pH site (Broadbalk 'Wilderness') than an acidic site (Geescroft 'Wilderness') due to differences in previous arable management (Poulton et al., 2003).

\section{Evidence for changes in subsoil OC stocks per unit area from the literature}

Changes in soil OC with depth over time found in the literature are summarised in Table 5 and given in full in Supplementary Information SI 2. To the best of our knowledge, there are currently only two sites in England and Wales with published data on subsoil OC taken at different points in time: Rothamsted in Hertfordshire (Poulton et al., 2003; Jenkinson et al., 2008) and Palace Leas in Northumberland (Hopkins et al., 2009). The UK Environmental Change Network (ECN) monitoring programme includes eight wellcharacterised terrestrial sites in England and Wales under a range of land uses where, amongst others, OC is measured on both a five- (to $30 \mathrm{~cm}$ depth) and 20-year (to $120 \mathrm{~cm}$ depth) sampling cycle from 1993 (ECN, 2013). This data is not available currently.

At Park Grass, since 1906 soil under long-term grassland has accumulated OC at a mean annual rate of over $15 \mathrm{~g} \mathrm{~m}^{-2}$ in the 30-100 $\mathrm{cm}$ layer, although this was off-set by an annual loss of $1 \mathrm{~g} \mathrm{~m}^{-2}$ in the upper $15 \mathrm{~cm}$ (Jenkinson et al., 2008). (Note that these estimates assume linear change over time, which may be erroneous over long intervals or following management changes - see Methodology.) Perhaps more surprising was that soils under long-term cultivation at Broadbalk accumulated OC at nearly $6 \mathrm{~g} \mathrm{~m}^{-2}$ annually over the same period in the same layer (Poulton et al., 2003). This represents a considerable sequestration, and might be partly explained by improved crop yields from advances in plant breeding and crop management over the 
past century, which will have increased the amount of OC returned to the soil. Palace Leas provides evidence of more recent changes (1982 to 2006). Average annual accumulations of OC were up to $8 \mathrm{~g} \mathrm{~m}^{-2}$ in the upper $30 \mathrm{~cm}$ in soils not receiving $\mathrm{N}$ fertiliser. Only in soils receiving $\mathrm{N}$ fertiliser was there a reported mean annual loss of OC $\left(-12 \mathrm{~g} \mathrm{~m}^{-2}\right)$ in the $15-30 \mathrm{~cm}$ depth, but this was offset by a large accumulation in the depth above. Hopkins et al. (2009) reported that any OC decreases were of the same order of magnitude as changes in bulk density (from which stocks are derived), itself dependent on water content, and that overall there were few significant changes in $\mathrm{OC}$ with time. Accumulation of OC at Palace Leas was far greater than at Park Grass, which may reflect the different soil and climatic conditions, Palace Leas being cooler and on a gley soil, whereas Park Grass is on a brown soil under warmer conditions.

There have been large increases in soil OC at the 'Wilderness' (naturally regenerated woodland) experiments at Broadbalk and Geescroft since the land was taken out of cultivation in the 1880s. Annual accumulation rates were initially greater for Broadbalk from the 1880s, but since the 1960s rates have been much greater for Geescroft $\left(47 \mathrm{~g} \mathrm{~m}^{-2}\right)$ than Broadbalk $\left(18 \mathrm{~g} \mathrm{~m}^{-2}\right)$ in the $15-100 \mathrm{~cm}$ layers (Poulton et al., 2003). The soil $\mathrm{pH}$ at Geescroft has fallen to 4.4 and there are few ground-cover plant species as a result, compared with Broadbalk which has retained its neutral $\mathrm{pH}$ through previous liming (Poulton et al., 2003). Increased acidity at Geescroft may have caused a slowing of organic matter decomposition and a consequent increase in the $\mathrm{OC}$ accumulation rate. More OC accumulated in the subsoil under managed and coarse grassland than under woodland at Broadbalk (Poulton et al., 2003). It is likely that soils take a considerable time to equilibrate to a change in land use (Poulton et al., 2003; Schipper et al., 2007; Smith et al., 2007). Subtle changes within land uses may also affect OC contents down the profile, such as different crop rooting patterns (Helfrich et al., 2007), use of fertilisers to increase the productivity, (Richards \& Webster, 1999; Hopkins et al., 2009) and use of different tillage practices (Vinten et al., 2002; Sun et al., 2011).

A full evaluation of the current dynamics of subsoil OC in England and Wales is not possible due to the lack of evidence. A comparison of the results here with measured changes in topsoil OC across the two countries (Bellamy et al., 2005; Kirk et al., 2013) is therefore premature. However, from our limited data there is no evidence of a significant change in OC stocks below $30 \mathrm{~cm}$ under long-term arable or grassland currently (Poulton et al., 2003; Jenkinson et al., 2008; Hopkins et al., 2009). Future assessments of the status and dynamics of subsoil OC stocks will benefit from a more systematic monitoring programme at benchmark sites (e.g. ECN, 2013) and advances in modelling (e.g. Jenkinson \& Coleman, 2008).

\section{Conclusions}

We estimate that the soils of England and Wales contain $3282 \mathrm{Tg}$ of $\mathrm{OC}$ in the upper $150 \mathrm{~cm}$, and that half of this (1649 Tg) is found below $30 \mathrm{~cm}$. Subsoil OC stocks vary with soil type and land use. Peat soils and other periodically wet soils have the largest OC stocks at depth. There is a general increase in soil OC stocks from cultivated land to grassland to other land uses reflecting, in part, differences in plant inputs and intensiveness of soil disturbances through management. Subsoil OC stocks probably equilibrate slowly over time when a change occurs, such as land use change. There is very little evidence with which to assess whether subsoil OC stocks in England and Wales are changing. What evidence we do have suggests that subsoil OC stocks under long-term management are stable.

\section{Acknowledgements}

This work was funded by the UK Department for Environment, Food and Rural Affairs (Project SP1106 "Soil carbon: studies to explore greenhouse gas emissions and mitigation"). Rothamsted Research uses facilities funded by the UK Biotechnology and Biological Sciences Research Council. This paper is published with the permission of the Executive Director of the British Geological Survey (UK Natural Environment Research Council).

\section{Supplementary Information}


The following information is available with the online version of this paper:

SI 1 Evidence from the literature of the soil organic C content and stock in the upper $200 \mathrm{~cm}$ of soils in England and Wales by soil type and land use.

SI 2 Evidence from the literature of the change in soil organic $C$ content and stock in the upper $100 \mathrm{~cm}$ of soils in England and Wales by soil type and land use.

\section{References}

Avery, B. W. 1980. Soil Classification for England and Wales (Higher Categories). Technical Monograph 14. Soil Survey of England and Wales, Harpenden, UK, pp. 67.

Avery, B. W. \& Bascomb, C. L. 1982. Soil Survey Laboratory Methods. Technical Monograph 6. Soil Survey of England and Wales, Harpenden, UK, pp. 83.

Avery, B. W. \& Catt, J. A. 1995. The Soil at Rothamsted. Lawes Agricultural Trust, Harpenden, UK, pp. 44.

Batjes, N. H. 1996. Total carbon and nitrogen in the soils of the world. European Journal of Soil Science, 47, $151-163$.

Bellamy, P. H., Loveland, P. J., Bradley, R. I., Lark, R. M. \& Kirk, G. J. D. 2005. Carbon losses from all soils across England and Wales 1978-2003. Nature, 437, 245-248.

Bernoux, M., Arrouays, D., Cerri, C. C. \& Bourennane, H. 1998. Modeling vertical distribution of carbon in oxisols of the western Brazilian Amazon (Rondônia). Soil Science, 163, 941-951.

Bradley, R. I., Milne, R., Bell, J., Lilly, A., Jordan, C. \& Higgins, A. 2005. A soil carbon and land use database for the United Kingdom. Soil Use and Management, 21, 363-369.

Chabbi, A., Kögel-Knabner, I. \& Rumpel, C. 2009. Stabilised carbon in subsoil horizons is located in spatially distinct parts of the soil profile. Soil Biology \& Biochemistry, 41, 256-261.

ECN 2013. UK Environmental Change Network [Online]. Available at: http://www.ecn.ac.uk; accessed 01/06/2013.

Ellis, S. \& Atherton, J. K. 2003. Properties and development of soils on reclaimed alluvial sediments of the Humber estuary, eastern England. Catena, 52, 129-147.

Emmett, B. A., Reynolds, B., Chamberlain, P. M., Rowe, E., Spurgeon, D., Brittain, S. A., Frogbrook, Z., Hughes, S., Lawlor, A. J., Poskitt, J., Potter, E., Robinson, D. A., Scott, A., Wood, C. \& Woods, C. 2010. Countryside Survey: Soils Report from 2007. Technical Report No. 9/07 (CEH Project Number: C03259). Natural Environment Research Council/Centre for Ecology \& Hydrology, Wallingford, Oxon., UK, pp. 192.

Fuller, R. M., Groom, G. B., Jones, A. R. \& Thomson, A. G. 1993. Countryside Survey 1990. Mapping the land cover of Great Britain using Landsat imagery: a demonstrator project in remote sensing. ITE Project No. T02052m5. Final report. Natural Environment Research Council/Institute of Terrestrial Ecology, Monk's Wood, Cambs, UK, pp. 71.

Garnett, M. H., Ineson, P., Stevenson, A. C. \& Howard, D. C. 2001. Terrestrial organic carbon storage in a British moorland. Global Change Biology, 7, 375-388.

Goidts, E. \& van Wesemael, B. 2007. Regional assessment of soil organic carbon changes under agriculture in Southern Belgium (1955-2005). Geoderma, 141, 341-354.

Hallett, S.H., Thanigasalam, P. \& Hollis, J.M. 1995. SEISMIC: a desktop information system for assessing the fate and behaviour of pesticides in the environment. Computers and Electronics in Agriculture, 13, 227-242.

Harrison, R. B., Footen, P. W. \& Strahm, B. D. 2011. Deep soil horizons: contribution and importance to soil carbon pools and in assessing whole-ecosystem response to management and global change. Forest Science, 57, 67-76.

Helfrich, M., Flessa, H., Mikutta, R., Dreves, A. \& Ludwig, B. 2007. Comparison of chemical fractionation methods for isolating stable soil organic carbon pools. European Journal of Soil Science, 58, 1316-1329.

Hopkins, D. W., Waite, I. S., McNicol, J. W., Poulton, P. R., Macdonald, A. J. \& O'Donnell, A. G. 2009. Soil organic carbon contents in long-term experimental grassland plots in the UK (Palace Leas and Park Grass) have not changed consistently in recent decades. Global Change Biology, 15, 1739-1754.

IUSS-ISRIC-FAO 2006. World Reference Base for Soil Resources 2006. World Soil Resources Report 103. Food and Agriculture Organization of the United Nations, Rome, Italy, pp. 128.

Jenkinson, D. S. 1971. The accumulation of organic matter in soil left uncultivated. In: Rothamsted Experimental Station. Report for 1970. Part 2, Lawes Agricultural Trust, Harpenden, UK, pp. 113-137.

Jenkinson, D. S. \& Coleman, K. 2008. The turnover of organic carbon in subsoils. Part 2. Modelling carbon turnover. European Journal of Soil Science, 59, 400-413.

Jenkinson, D. S., Poulton, P. R. \& Bryant, C. 2008. The turnover of organic carbon in subsoils. Part 1. Natural and bomb radiocarbon in soil profiles from the Rothamsted long-term field experiments. European Journal of Soil Science, 59, 391399.

Jobbágy, E. G. \& Jackson, R. B. 2000. The vertical distribution of soil organic carbon and its relation to climate and vegetation. Ecological Applications, 10, 423-436.

King, J. A., Bradley, R. I. \& Harrison, R. 2005. Current trends of soil organic carbon in English arable soils. Soil Use and Management, 21, 189-195. 
Kirk, G. J. D., Bellamy, P. H., Emmett, B. A. \& Scott, A. 2013. Comparison of topsoil carbon changes across England and Wales estimated in the Countryside Survey and the National Soil Inventory. Defra Project SP1101. Research Project Final Report. Department of Environment, Food and Rural Affairs, London, UK.

Mackney, D., Hodgson, J. M., Hollis, J. M. \& Staines, S. J. 1983. The 1:250000 National Soil Map of England and Wales. Soil Survey of England and Wales, Harpenden, UK.

Malone, B. P., McBratney, A. B. \& Minasny, B. 2011. Empirical estimates of uncertainty for mapping continuous depth functions of soil attributes. Geoderma, 160, 614-626.

Nelson, D. W. \& Sommers, L. E. 1996. Total carbon, organic carbon, and organic matter. In: Methods of Soil Analysis. Part 3. Chemical Methods (ed. D. L. Sparks), ASA, SSSA, Madison, WI, USA, pp. 961-1010.

Odgers, N. P., Libohova, Z. \& Thompson, J. A. 2012. Equal-area spline functions applied to a legacy soil database to create weighted-means maps of soil organic carbon at a continental scale. Geoderma, 189, 153-163.

Poeplau, C., Don, A., Vesterdal, L., Leifeld, J., Van Wesemael, B., Schumacher, J. \& Gensior, A. 2011. Temporal dynamics of soil organic carbon after land-use change in the temperate zone - carbon response functions as a model approach. Global Change Biology, 17, 2415-2427.

Poulton, P. R., Pye, E., Hargreaves, P. R. \& Jenkinson, D. S. 2003. Accumulation of carbon and nitrogen by old arable land reverting to woodland. Global Change Biology, 9, 942-955.

Proctor, M. E., Siddons, P. A., Jones, R. J. A., Bellamy, P. H. \& Keay, C. A. 1998. LandIS - a land information system for the UK. In: Land Information Systems: Developments for Planning the Sustainable Use of Land Resources. European Soil Bureau Research Report No. 4. EUR 17729 EN. (eds H. J. Heineke, W. Eckelmann, A. J. Thomasson, R. J. A. Jones, L. Montanarella \& B. Buckley), Office for Official Publications of the European Communities, Luxembourg, pp. $219-233$.

Rawlins, B. G., Vane, C. H., Kim, A. W. \& Moss-Hayes., V. 2009. Preliminary investigations of Black Carbon occurrence in peats on Broomhead Moor, South Yorkshire. Internal Report IR/08/096. British Geological Survey, Keyworth, UK, pp. 20.

Richards, J. E. \& Webster, C. P. 1999. Denitrification in the subsoil of the Broadbalk Continuous Wheat Experiment. Soil Biology \& Biochemistry, 31, 747-755.

Rumpel, C. \& Kögel-Knabner, I. 2011. Deep soil organic matter - a key but poorly understood component of terrestrial C cycle. Plant and Soil, 338, 143-158.

Saby, N. P. A., Arrouays, D., Antoni, V., Lemercier, B., Follain, S., Walter, C. \& Schvartz, C. 2008. Changes in soil organic carbon in a mountainous French region, 1990-2004. Soil Use and Management, 24, 254-262.

Schipper, L. A., Baisden, W. T., Parfitt, R. L., Ross, C., Claydon, J. J. \& Arnold, G. 2007. Large losses of soil C and N from soil profiles under pasture in New Zealand during the past 20 years. Global Change Biology, 13, 1138-1144.

Schmidt, M. W. I., Torn, M. S., Abiven, S., Dittmar, T., Guggenberger, G., Janssens, I. A., Kleber, M., Kögel-Knabner, I., Lehmann, J., Manning, D. A. C., Nannipieri, P., Rasse, D. P., Weiner, S. \& Trumbore, S. E. 2011. Persistence of soil organic matter as an ecosystem property. Nature, 478, 49-56.

Shiel, R. S. 1986. Variation in amounts of carbon and nitrogen associated with particle size fractions of soils from the Palace Leas meadow hay plots. Journal of Soil Science, 37, 249-257.

Smith, P., Chapman, S. J., Scott, W. A., Black, H. I. J., Wattenbach, M., Milne, R., Campbell, C. D., Lilly, A., Ostle, N., Levy, P. E., Lumsdon, D. G., Millard, P., Towers, W., Zaehle, S. \& Smith, J. U. 2007. Climate change cannot be entirely responsible for soil carbon loss observed in England and Wales, 1978-2003. Global Change Biology, 13, $2605-2609$.

Sun, B., Hallett, P. D., Caul, S., Daniell, T. J. \& Hopkins, D. W. 2011. Distribution of soil carbon and microbial biomass in arable soils under different tillage regimes. Plant and Soil, 338, 17-25.

Tye, A. M. 2010. Nitrogen and carbon stocks and species in soils, sediments and groundwater of a shallow floodplain aquifer in the Trent Valley. Land Use and Development Programme. Open Report OR/10/069. British Geological Survey, Keyworth, UK, pp. 105.

Vinten, A. J. A., Ball, B. C., O'Sullivan, M. F. \& Henshall, J. K. 2002. The effects of cultivation method, fertilizer input and previous sward-type on organic $\mathrm{C}$ and $\mathrm{N}$ storage and gaseous losses under spring and-winter barley following long-term leys. Journal of Agricultural Science, 139, 231-243.

Wiesmeier, M., Spörlein, P., Geuß, U., Hangen, E., Haug, S., Reischl, A., Schilling, B., von Lützow, M. \& Kögel-Knabner, I. 2012. Soil organic carbon stocks in southeast Germany (Bavaria) as affected by land use, soil type and sampling depth. Global Change Biology, 18, 2233-2245.

Wilson, B. R., Moffatt, A. J. \& Nortcliff, S. 1997. The nature of three ancient woodland soils in southern England. Journal of Biogeography, 24, 633-646. 
Table 1 The Major Soil Groups ${ }^{\mathrm{a}}$ of the SSEW soil classification system (Avery, 1980).

\begin{tabular}{|c|c|}
\hline Major Soil Group & Description \\
\hline Lithomorphic soils & $\begin{array}{l}\text { With distinct humose or organic topsoil over } \mathrm{C} \text { horizon or bedrock at } 40 \mathrm{~cm} \text { or less and no } \\
\text { diagnostic } \mathrm{B} \text { or gleyed horizon within that depth }\end{array}$ \\
\hline Pelosols & $\begin{array}{l}\text { Slowly permeable (when wet) non-alluvial clayey soils with B or BC horizon showing vertic } \\
\text { features and no E, non-calcareous BG or paleo-argillic horizon }\end{array}$ \\
\hline Brown soils & $\begin{array}{l}\text { Soils excluding pelosols, with weathered, argillic or paleo-argillic } \mathrm{B} \text { and no diagnostic } \\
\text { gleyed horizon at } 40 \mathrm{~cm} \text { or less }\end{array}$ \\
\hline Podzolic soils & With podzolic B horizon \\
\hline Surface-water gley soils & $\begin{array}{l}\text { Non-alluvial soils with distinct, humose or peaty topsoil, non-calcareous } \mathrm{Eg} \text { and/or } \mathrm{Bg} \text { or } \\
\text { Btg horizon and no G or relatively pervious Cg horizon affected by free groundwater }\end{array}$ \\
\hline Ground-water gley soils & $\begin{array}{l}\text { With distinct humose or peaty topsoil and diagnostic gleyed horizon at less than } 40 \mathrm{~cm} \text { in } \\
\text { recent alluvium ripened to more than } 20 \mathrm{~cm} \text {, and/or with } \mathrm{G} \text { or relatively pervious } \mathrm{Cg} \text { horizon } \\
\text { affected by free ground water }\end{array}$ \\
\hline Man-made soils & $\begin{array}{l}\text { With thick man-made A horizon or disturbed soil (including material recognisably derived } \\
\text { from pedogenic horizons) more than } 40 \mathrm{~cm} \text { thick }\end{array}$ \\
\hline Peat soils & $\begin{array}{l}\text { Having more than a specified content of OC, depending on the clay content of the mineral } \\
\text { fraction }\end{array}$ \\
\hline
\end{tabular}

${ }^{a}$ Terrestrial raw soils and Raw gley soils omitted (they account for $<1 \%$ of the land area) 
Table 2 Depth-distributions of soil organic C (OC) stock per unit area in the upper $150 \mathrm{~cm}$ of soils in England and Wales by SSEW Major Soil Group and land use. $\mathrm{SD}=$ standard deviation.

\begin{tabular}{|c|c|c|c|c|c|c|c|c|c|c|c|}
\hline \multirow{3}{*}{$\begin{array}{l}\text { Land use } \\
\text { Major Soil Group }\end{array}$} & \multirow{3}{*}{$\begin{array}{c}\text { Number of } \\
\text { soil series } \\
n\end{array}$} & \multicolumn{7}{|c|}{ OC stock per unit area $\left(\mathrm{kg} \mathrm{m}^{-2}\right)$} & \multicolumn{3}{|c|}{ Fraction of total $0-150 \mathrm{~cm}$ stock (\%) } \\
\hline & & \multicolumn{2}{|c|}{$0-30 \mathrm{~cm}$} & \multicolumn{2}{|c|}{$30-100 \mathrm{~cm}$} & \multicolumn{2}{|c|}{$100-150 \mathrm{~cm}$} & \multirow{2}{*}{$\frac{0-150 \mathrm{~cm}}{\text { Mean }}$} & \multirow[t]{2}{*}{$0-30 \mathrm{~cm}$} & \multirow[t]{2}{*}{$30-100 \mathrm{~cm}$} & \multirow[t]{2}{*}{$100-150 \mathrm{~cm}$} \\
\hline & & Mean & SD & Mean & SD & Mean & SD & & & & \\
\hline \multicolumn{12}{|l|}{ Cultivated land } \\
\hline Lithomorphic soils & 33 & 9.97 & 2.95 & 0.52 & 3.36 & 0.26 & 3.09 & 10.75 & 92.7 & 4.8 & 2.5 \\
\hline Pelosols & 11 & 8.46 & 0.69 & 5.38 & 0.71 & 2.46 & 0.65 & 16.30 & 51.9 & 33.0 & 15.1 \\
\hline Brown soils & 188 & 6.67 & 0.25 & 3.96 & 0.29 & 0.96 & 0.17 & 11.59 & 57.6 & 34.1 & 8.3 \\
\hline Podzolic soils & 50 & 11.89 & 1.73 & 5.94 & 0.70 & 1.22 & 0.22 & 19.07 & 62.4 & 31.2 & 6.4 \\
\hline Surface-water gley soils & 58 & 7.63 & 1.44 & 4.57 & 0.62 & 1.66 & 0.49 & 13.86 & 55.1 & 33.0 & 12.0 \\
\hline Ground-water gley soils & 64 & 12.34 & 1.99 & 8.19 & 2.64 & 4.21 & 1.77 & 24.75 & 49.9 & 33.1 & 17.0 \\
\hline Man-made soils & 19 & 5.13 & 1.96 & 0.44 & 0.81 & 0.10 & 0.29 & 5.68 & 90.4 & 7.8 & 1.8 \\
\hline Peat soils & 7 & 36.67 & 4.09 & 82.99 & 5.55 & 46.29 & 4.94 & 165.99 & 22.1 & 50.0 & 27.9 \\
\hline \multicolumn{12}{|c|}{ Permanent managed grassland } \\
\hline Lithomorphic soils & 33 & 11.78 & 2.39 & 0.58 & 3.05 & 0.11 & 2.85 & 12.47 & 94.5 & 4.6 & 0.9 \\
\hline Pelosols & 11 & 10.49 & 1.11 & 6.76 & 1.06 & 2.26 & 0.59 & 19.51 & 53.8 & 34.6 & 11.6 \\
\hline Brown soils & 188 & 9.29 & 0.42 & 4.73 & 0.34 & 0.86 & 0.19 & 14.88 & 62.4 & 31.8 & 5.8 \\
\hline Podzolic soils & 50 & 13.22 & 2.53 & 6.17 & 1.10 & 1.00 & 0.36 & 20.39 & 64.8 & 30.2 & 4.9 \\
\hline Surface-water gley soils & 58 & 10.80 & 1.30 & 5.77 & 0.65 & 1.80 & 0.48 & 18.37 & 58.8 & 31.4 & 9.8 \\
\hline Ground-water gley soils & 64 & 11.93 & 2.21 & 7.99 & 2.45 & 3.89 & 1.66 & 23.82 & 50.1 & 33.6 & 16.3 \\
\hline Man-made soils & 19 & 5.98 & 2.95 & 0.12 & 1.02 & 0.01 & 0.36 & 6.11 & 97.8 & 2.0 & 0.2 \\
\hline Peat soils & 7 & 31.77 & 4.75 & 76.63 & 3.08 & 50.88 & 3.17 & 159.22 & 19.9 & 48.1 & 31.9 \\
\hline \multicolumn{12}{|l|}{ Other land uses } \\
\hline$\overline{\text { Lithomorphic soils }}$ & 33 & 13.90 & 1.99 & 0.47 & 2.49 & 0.11 & 2.33 & 14.48 & 96.0 & 3.2 & 0.8 \\
\hline Pelosols & 11 & 9.67 & 0.97 & 5.92 & 0.54 & 2.18 & 0.51 & 17.77 & 54.4 & 33.3 & 12.3 \\
\hline Brown soils & 188 & 9.08 & 0.47 & 4.31 & 0.34 & 0.79 & 0.19 & 14.18 & 64.0 & 30.4 & 5.6 \\
\hline Podzolic soils & 50 & 18.55 & 2.12 & 5.33 & 0.70 & 0.80 & 0.24 & 24.67 & 75.2 & 21.6 & 3.2 \\
\hline Surface-water gley soils & 58 & 15.46 & 2.04 & 8.11 & 0.90 & 2.17 & 0.57 & 25.74 & 60.1 & 31.5 & 8.4 \\
\hline Ground-water gley soils & 64 & 14.38 & 2.38 & 6.42 & 2.37 & 2.61 & 1.65 & 23.41 & 61.4 & 27.4 & 11.2 \\
\hline Man-made soils & 19 & 4.88 & 2.56 & 0.04 & 0.88 & 0.00 & 0.32 & 4.92 & 99.1 & 0.8 & 0.0 \\
\hline Peat soils & 7 & 30.75 & 9.70 & 79.53 & 7.14 & 58.08 & 5.07 & 168.38 & 18.3 & 47.2 & 34.5 \\
\hline
\end{tabular}


Table 3 Depth-distributions of total soil organic C (OC) stocks in the upper $150 \mathrm{~cm}$ of soils in England and Wales by SSEW Major Soil Group and land use. Note the totals include the small contributions $(<0.2 \%)$ of Terrestrial raw soils and Raw gley soils

\begin{tabular}{|c|c|c|c|c|}
\hline \multirow{2}{*}{$\begin{array}{l}\text { Land use } \\
\text { Major Soil Group }\end{array}$} & \multirow{2}{*}{$\begin{array}{l}\text { Area } \\
\left(\mathrm{km}^{2}\right)\end{array}$} & \multicolumn{3}{|c|}{ Total OC stock $(\mathrm{Tg})$} \\
\hline & & $0-30 \mathrm{~cm}$ & $30-100 \mathrm{~cm}$ & $100-150 \mathrm{~cm}$ \\
\hline \multicolumn{5}{|l|}{ Cultivated land } \\
\hline Lithomorphic soils & 3769 & 38 & 2 & 1 \\
\hline Pelosols & 5332 & 45 & 29 & 13 \\
\hline Brown soils & 19929 & 133 & 79 & 19 \\
\hline Podzolic soils & 797 & 9 & 5 & 1 \\
\hline Surface-water gley soils & 11559 & 88 & 53 & 19 \\
\hline Ground-water gley soils & 6171 & 77 & 51 & 26 \\
\hline Man-made soils & 163 & 1 & 0 & 0 \\
\hline Peat soils & 741 & 27 & 62 & 34 \\
\hline Total for land use & 48461 & 419 & 279 & 114 \\
\hline \multicolumn{5}{|l|}{ Permanent managed grassland } \\
\hline Lithomorphic soils & 3810 & 45 & 2 & 0 \\
\hline Pelosols & 2607 & 27 & 18 & 6 \\
\hline Brown soils & 26670 & 248 & 127 & 23 \\
\hline Podzolic soils & 4876 & 65 & 30 & 5 \\
\hline Surface-water gley soils & 18077 & 195 & 104 & 33 \\
\hline Ground-water gley soils & 4664 & 56 & 37 & 18 \\
\hline Man-made soils & 238 & 1 & 0 & 0 \\
\hline Peat soils & 719 & 23 & 55 & 37 \\
\hline Total for land use & 61661 & 660 & 373 & 121 \\
\hline \multicolumn{5}{|l|}{ Other land uses } \\
\hline Lithomorphic soils & 2232 & 33 & 1 & 0 \\
\hline Pelosols & 681 & 7 & 4 & 1 \\
\hline Brown soils & 10322 & 94 & 45 & 8 \\
\hline Podzolic soils & 6098 & 114 & 33 & 5 \\
\hline Surface-water gley soils & 9850 & 152 & 80 & 21 \\
\hline Ground-water gley soils & 2206 & 31 & 14 & 6 \\
\hline Man-made soils & 197 & 1 & 0 & 0 \\
\hline Peat soils & 3936 & 121 & 313 & 229 \\
\hline Total for land use & 35522 & 554 & 490 & 271 \\
\hline Total for England and Wales & 145644 & 1633 & 1143 & 506 \\
\hline
\end{tabular}


Table 4 Evidence from the literature of the soil organic C (OC) stock in the upper $150 \mathrm{~cm}$ of soils in England and Wales by SSEW Major Soil Group (Avery, 1980) (and WRB Reference Soil Group, IUSSISRIC-FAO, 2006).

\begin{tabular}{|c|c|c|c|c|c|c|}
\hline $\begin{array}{l}\text { Land use } \\
\text { Major Soil Group } \\
\text { [WRB Reference Soil } \\
\text { Group] }\end{array}$ & Location & Parent material & $\begin{array}{l}\text { Depth } \\
(\mathrm{cm})\end{array}$ & $\begin{array}{l}\text { OC stock } \\
\left(\mathrm{kg} \mathrm{m}^{-2}\right)\end{array}$ & Notes & Reference \\
\hline \multicolumn{7}{|l|}{ Cultivated land } \\
\hline $\begin{array}{l}\text { Pelosol } \\
\text { [Luvisol] }\end{array}$ & Shelford, Notts. & Triassic mudstone & $\begin{array}{c}0-30 \\
30-100\end{array}$ & $\begin{array}{l}3.40 \\
1.75\end{array}$ & $\begin{array}{l}\text { Soil under mixed arable } \\
\text { use }\end{array}$ & Tye, 2010 \\
\hline $\begin{array}{l}\text { Brown soil } \\
\text { [Luvisol] }\end{array}$ & $\begin{array}{l}\text { Broadbalk, } \\
\text { Rothamsted, Herts. }\end{array}$ & Cretaceous chalk-with-flints & $\begin{array}{c}0-30 \\
30-100\end{array}$ & $\begin{array}{l}3.94 \\
4.75\end{array}$ & $\begin{array}{l}\text { Long-term wheat with } \mathrm{N} \text { - } \\
\text { fertiliser }\end{array}$ & $\begin{array}{l}\text { Poulton et al., } \\
2003\end{array}$ \\
\hline $\begin{array}{l}\text { Brown soil } \\
\text { [Cambisol] }\end{array}$ & $\begin{array}{l}\text { Sunk Island, E. } \\
\text { Yorks. }\end{array}$ & $\begin{array}{l}\text { Alluvium over Quaternary } \\
\text { glacial and lacustrine } \\
\text { sediment }\end{array}$ & $\begin{array}{c}0-30 \\
30-100 \\
100-150\end{array}$ & $\begin{array}{r}10.16 \\
8.41 \\
4.55\end{array}$ & $\begin{array}{l}\text { Mean of two soils } \\
\text { reclaimed from estuary }\end{array}$ & $\begin{array}{l}\text { Ellis \& Atherton } \\
2003\end{array}$ \\
\hline $\begin{array}{l}\text { Brown soil } \\
{[\text { Cambisol/Luvisol] }}\end{array}$ & Shelford, Notts. & $\begin{array}{l}\text { Recent head and alluvial sand } \\
\text { over Triassic sandstone }\end{array}$ & $\begin{array}{c}0-30 \\
30-100\end{array}$ & $\begin{array}{l}7.12 \\
6.06\end{array}$ & $\begin{array}{l}\text { Mean of five soils under } \\
\text { mixed arable }\end{array}$ & Tye, 2010 \\
\hline $\begin{array}{l}\text { Surface-water gley soil } \\
\text { [Luvisol] }\end{array}$ & Shelford, Notts. & Triassic mudstone & $\begin{array}{c}0-30 \\
30-100\end{array}$ & $\begin{array}{l}3.19 \\
1.62\end{array}$ & $\begin{array}{l}\text { Soil under mixed arable } \\
\text { use }\end{array}$ & Tye, 2010 \\
\hline $\begin{array}{l}\text { Ground-water gley soil } \\
\text { [Fluvisol] }\end{array}$ & $\begin{array}{l}\text { Sunk Island, E. } \\
\text { Yorks. }\end{array}$ & $\begin{array}{l}\text { Alluvium over Quaternary } \\
\text { glacial and lacustrine } \\
\text { sediment }\end{array}$ & $\begin{array}{c}0-30 \\
30-100 \\
100-150\end{array}$ & $\begin{array}{r}6.49 \\
10.33 \\
4.57\end{array}$ & $\begin{array}{l}\text { Mean of two soils } \\
\text { reclaimed from estuary }\end{array}$ & $\begin{array}{l}\text { Ellis \& Atherton } \\
2003\end{array}$ \\
\hline $\begin{array}{l}\text { Ground-water gley soil } \\
\text { [Fluvisol/Gleysol] }\end{array}$ & Shelford, Notts. & $\begin{array}{l}\text { Alluvial gravel, sand and clay } \\
\text { over Triassic mudstone }\end{array}$ & $\begin{array}{c}0-30 \\
30-100\end{array}$ & $\begin{array}{l}8.42 \\
2.06\end{array}$ & $\begin{array}{l}\text { Mean of four soils under } \\
\text { mixed arable }\end{array}$ & Tye, 2010 \\
\hline Various & $\begin{array}{l}\text { Several locations, } \\
\text { England and Wales }\end{array}$ & NA & $\begin{array}{c}0-30 \\
30-100\end{array}$ & $\begin{array}{r}7.00 \\
4.00-5.00\end{array}$ & All cultivated soils & $\begin{array}{l}\text { Bradley et al., } \\
2005\end{array}$ \\
\hline \multicolumn{7}{|c|}{ Permanent managed grassland } \\
\hline $\begin{array}{l}\text { Brown soil } \\
\text { [Luvisol] }\end{array}$ & $\begin{array}{l}\text { Park Grass, } \\
\text { Rothamsted, Herts. }\end{array}$ & Cretaceous chalk-with-flints & $\begin{array}{c}0-15 \\
15-30 \\
30-100\end{array}$ & $\begin{array}{l}5.20 \\
3.55 \\
5.13\end{array}$ & $\begin{array}{l}\text { Mean of three long-term } \\
\text { treatments }\end{array}$ & $\begin{array}{l}\text { Jenkinson et al., } \\
2008\end{array}$ \\
\hline $\begin{array}{l}\text { Brown soil } \\
\text { [Luvisol] }\end{array}$ & $\begin{array}{l}\text { Broadbalk } \\
\text { Wilderness, } \\
\text { Rothamsted, Herts. }\end{array}$ & Cretaceous chalk-with-flints & $\begin{array}{c}0-15 \\
15-30 \\
30-100\end{array}$ & $\begin{array}{l}4.68 \\
3.19 \\
5.18\end{array}$ & $\begin{array}{l}\text { Grazed grass from natural } \\
\text { regeneration }\end{array}$ & $\begin{array}{l}\text { Poulton et al., } \\
2003\end{array}$ \\
\hline $\begin{array}{l}\text { Brown soil } \\
\text { [Cambisol] }\end{array}$ & $\begin{array}{l}\text { Sunk Island, E. } \\
\text { Yorks. }\end{array}$ & $\begin{array}{l}\text { Alluvium over Quaternary } \\
\text { glacial and lacustrine } \\
\text { sediment }\end{array}$ & $\begin{array}{c}0-15 \\
15-30 \\
30-100\end{array}$ & $\begin{array}{r}4.66 \\
4.61 \\
11.47\end{array}$ & $\begin{array}{l}\text { Soil reclaimed from } \\
\text { estuary }\end{array}$ & $\begin{array}{l}\text { Ellis \& Atherton } \\
2003\end{array}$ \\
\hline $\begin{array}{l}\text { Surface-water gley soil } \\
\text { [Luvisol] } \\
\text { Surface-water gley soil } \\
\text { [Luvisol] } \\
\text { Various }\end{array}$ & $\begin{array}{l}\text { Palace Leas, Cockle } \\
\text { Park, Northumb. } \\
\text { Palace Leas, Cockle } \\
\text { Park, Northumb. } \\
\text { Several locations, } \\
\text { England and Wales }\end{array}$ & $\begin{array}{l}\text { Carboniferous shale } \\
\text { Carboniferous shale } \\
\text { NA }\end{array}$ & $\begin{array}{c}0-15 \\
15-30 \\
0-15 \\
15-30 \\
0-30 \\
30-100\end{array}$ & $\begin{array}{r}6.25 \\
3.43 \\
12.72 \\
2.87 \\
8.00-9.00 \\
5.00\end{array}$ & $\begin{array}{l}\text { Mean of four treatments, } \\
\text { no N } \\
\text { Mean of two treatments } \\
\text { with N } \\
\text { All permanent grassland } \\
\text { soils }\end{array}$ & $\begin{array}{l}\text { Hopkins et al., } \\
2009 \\
\text { Hopkins et al., } \\
2009 \\
\text { Bradley et al., } \\
2005\end{array}$ \\
\hline \multicolumn{7}{|l|}{ Other land uses } \\
\hline $\begin{array}{l}\text { Brown soil } \\
\text { [Luvisol] }\end{array}$ & $\begin{array}{l}\text { Broadbalk } \\
\text { Wilderness, } \\
\text { Rothamsted, Herts. }\end{array}$ & Cretaceous chalk-with-flints & $\begin{array}{c}0-15 \\
15-30 \\
30-100\end{array}$ & $\begin{array}{l}5.35 \\
3.68 \\
5.87\end{array}$ & $\begin{array}{l}\text { Coarse grasses from } \\
\text { natural regeneration }\end{array}$ & $\begin{array}{l}\text { Poulton et al., } \\
2003\end{array}$ \\
\hline $\begin{array}{l}\text { Brown soil } \\
\text { [Luvisol] }\end{array}$ & $\begin{array}{l}\text { Broadbalk } \\
\text { Wilderness, } \\
\text { Rothamsted, Herts. }\end{array}$ & Cretaceous chalk-with-flints & $\begin{array}{c}0-15 \\
15-30 \\
30-100\end{array}$ & $\begin{array}{l}5.09 \\
3.49 \\
6.05\end{array}$ & $\begin{array}{l}\text { Regenerated mixed } \\
\text { deciduous woodland }\end{array}$ & $\begin{array}{l}\text { Poulton et al., } \\
2003\end{array}$ \\
\hline $\begin{array}{l}\text { Brown soil } \\
\text { [Luvisol] }\end{array}$ & $\begin{array}{l}\text { Geescroft } \\
\text { Wilderness, } \\
\text { Rothamsted, Herts. }\end{array}$ & Cretaceous chalk-with-flints & $\begin{array}{c}0-15 \\
15-30 \\
30-100\end{array}$ & $\begin{array}{l}4.12 \\
2.91 \\
5.07\end{array}$ & $\begin{array}{l}\text { Mean of two soils under } \\
\text { regenerated oak and ash } \\
\text { woodland }\end{array}$ & $\begin{array}{l}\text { Poulton et al., } \\
2003\end{array}$ \\
\hline $\begin{array}{l}\text { Brown soil } \\
\text { [Cambisol] }\end{array}$ & $\begin{array}{l}\text { Frilsham and } \\
\text { Binfield, Berks. }\end{array}$ & $\begin{array}{l}\text { Tertiary London Clay (with or } \\
\text { without loess) }\end{array}$ & $\begin{array}{c}0-15 \\
15-30\end{array}$ & $\begin{array}{l}6.30 \\
3.40\end{array}$ & $\begin{array}{l}\text { Mean of two soils under } \\
\text { ancient oak woodland }\end{array}$ & $\begin{array}{l}\text { Wilson et al., } \\
1997\end{array}$ \\
\hline Brown soil & $\begin{array}{l}\text { Yattendon and } \\
\text { Binfield, Berks. }\end{array}$ & $\begin{array}{l}\text { Tertiary London Clay (with or } \\
\text { without loess) }\end{array}$ & $\begin{array}{c}0-15 \\
15-30\end{array}$ & $\begin{array}{l}4.90 \\
2.30\end{array}$ & $\begin{array}{l}\text { Mean of two soils under } \\
\text { oak plantation }\end{array}$ & $\begin{array}{l}\text { Wilson et al., } \\
1997\end{array}$ \\
\hline $\begin{array}{l}\text { Podzolic soil } \\
\text { [Cambisol] }\end{array}$ & Bolderwood, Hants. & Tertiary Barton Sand & $\begin{array}{c}0-15 \\
15-30\end{array}$ & $\begin{array}{l}4.90 \\
2.40\end{array}$ & $\begin{array}{l}\text { Ancient oak and beech } \\
\text { woodland }\end{array}$ & $\begin{array}{l}\text { Wilson et al., } \\
1997\end{array}$ \\
\hline $\begin{array}{l}\text { Podzolic soil } \\
\text { [Cambisol] }\end{array}$ & Bolderwood, Hants. & Tertiary Barton Sand & $\begin{array}{c}0-15 \\
15-30\end{array}$ & $\begin{array}{l}6.90 \\
2.50\end{array}$ & Oak and beech plantation & $\begin{array}{l}\text { Wilson et al., } \\
1997\end{array}$ \\
\hline $\begin{array}{l}\text { Raw peat soil } \\
\text { [Histosols] }\end{array}$ & $\begin{array}{l}\text { Moor House, } \\
\text { Cumbria }\end{array}$ & $\begin{array}{l}\text { Limestone bedrock and glacial } \\
\text { till }\end{array}$ & $\begin{array}{c}0-30 \\
30-100\end{array}$ & $\begin{array}{l}4.70-17.60 \\
2.10-31.90\end{array}$ & $\begin{array}{l}\text { Data from soils under } \\
\text { moorland }\end{array}$ & $\begin{array}{l}\text { Garnett et al., } \\
2001\end{array}$ \\
\hline $\begin{array}{l}\text { Raw peat soil } \\
\text { [Histosols] }\end{array}$ & $\begin{array}{l}\text { Broomhead Moor, } \\
\text { S. Yorks. }\end{array}$ & Carboniferous Millstone Grit & $\begin{array}{c}0-30 \\
30-100 \\
100-150\end{array}$ & $\begin{array}{l}11.00-28.70 \\
25.60-66.90 \\
18.30-47.80\end{array}$ & $\begin{array}{l}\text { Data from soils under } \\
\text { moorland }\end{array}$ & $\begin{array}{l}\text { Rawlins et al., } \\
2009\end{array}$ \\
\hline Various & $\begin{array}{l}\text { Several locations, } \\
\text { England and Wales }\end{array}$ & NA & $\begin{array}{c}0-30 \\
30-100\end{array}$ & $\begin{array}{l}11.00-12.00 \\
12.00-17.00\end{array}$ & $\begin{array}{l}\text { All semi-natural } \\
\text { (vegetated) soils }\end{array}$ & $\begin{array}{l}\text { Bradley et al., } \\
2005\end{array}$ \\
\hline Various & $\begin{array}{l}\text { Several locations, } \\
\text { England and Wales }\end{array}$ & NA & $\begin{array}{c}0-30 \\
30-100\end{array}$ & $\begin{array}{r}10.00-12.00 \\
7.00-8.00\end{array}$ & All woodland soils & $\begin{array}{l}\text { Bradley et al., } \\
2005\end{array}$ \\
\hline
\end{tabular}


Table 5 Evidence from the literature on changes in soil organic C (OC) stocks over time in the upper 100 $\mathrm{cm}$ of soils in England and Wales by SSEW Soil Group (Avery, 1980) under continuous land use or land use change. Refer to Table 4 for further site and soil details.

\begin{tabular}{|c|c|c|c|c|c|c|}
\hline $\begin{array}{l}\text { Continuous land use or } \\
\text { land use change } \\
\text { Soil Group }\end{array}$ & Location & $\begin{array}{l}\text { Years of } \\
\text { monitoring }\end{array}$ & $\begin{array}{l}\text { Depth } \\
(\mathrm{cm})\end{array}$ & $\begin{array}{l}\text { Change in OC } \\
\text { stock } \\
\left(\mathrm{g} \mathrm{m}^{-2} \text { year }^{-1}\right)\end{array}$ & Notes & Reference \\
\hline \multicolumn{7}{|c|}{ Continuous: Cultivated land } \\
\hline Brown soil & $\begin{array}{l}\text { Broadbalk, } \\
\text { Rothamsted, Herts. }\end{array}$ & $\begin{array}{l}1893-1904 \\
1904-1999\end{array}$ & $\begin{array}{c}0-30 \\
30-100 \\
0-30 \\
30-100\end{array}$ & $\begin{array}{l}+23.3 \\
+7.1 \\
+2.7 \\
+5.8\end{array}$ & $\begin{array}{l}\text { Long-term wheat } \\
\text { with N-fertiliser }\end{array}$ & Poulton et al., 2003 \\
\hline \multicolumn{7}{|c|}{ Continuous: Permanent managed grassland } \\
\hline Brown soil & $\begin{array}{l}\text { Park Grass, } \\
\text { Rothamsted, Herts. }\end{array}$ & $\begin{array}{l}1870-1876 \\
1876-1906\end{array}$ & $\begin{array}{c}0-15 \\
15-30 \\
30-100 \\
0-15 \\
15-30 \\
30-100 \\
0-15 \\
15-30 \\
30-100\end{array}$ & $\begin{array}{r}-86.9 \\
-64.1 \\
-75.6 \\
+0.3 \\
-0.3 \\
+0.8 \\
-1.0 \\
+1.1 \\
+15.4\end{array}$ & $\begin{array}{l}\text { Mean of two long- } \\
\text { term treatments }\end{array}$ & Jenkinson et al., 2008 \\
\hline Surface-water gley soil & $\begin{array}{l}\text { Palace Leas, Cockle } \\
\text { Park, Northumb. }\end{array}$ & $1982-2006$ & $\begin{array}{c}0-15 \\
15-30\end{array}$ & $\begin{array}{l}+5.3 \\
+7.8\end{array}$ & $\begin{array}{l}\text { Mean of four } \\
\text { treatments, no N }\end{array}$ & Hopkins et al., 2009 \\
\hline Surface-water gley soil & $\begin{array}{l}\text { Palace Leas, Cockle } \\
\text { Park, Northumb. }\end{array}$ & $1982-2006$ & $\begin{array}{c}0-15 \\
15-30\end{array}$ & $\begin{array}{l}+85.1 \\
-12.1\end{array}$ & $\begin{array}{l}\text { Mean of two } \\
\text { treatments with N }\end{array}$ & Hopkins et al., 2009 \\
\hline \multicolumn{7}{|c|}{ Change: Cultivated land to Permanent managed grassland } \\
\hline Brown soil & $\begin{array}{l}\text { Broadbalk } \\
\text { Wilderness, } \\
\text { Rothamsted, Herts. }\end{array}$ & 1881-1999 & $\begin{array}{c}0-15 \\
15-30 \\
30-100\end{array}$ & $\begin{array}{l}+25.0 \\
+14.6 \\
+10.4\end{array}$ & $\begin{array}{l}\text { Wheat to grazed } \\
\text { grassland }\end{array}$ & Poulton et al., 2003 \\
\hline \multicolumn{7}{|c|}{ Change: Cultivated land to Other land uses } \\
\hline Brown soil & $\begin{array}{l}\text { Broadbalk } \\
\text { Wilderness, } \\
\text { Rothamsted, Herts. }\end{array}$ & 1964-1999 & $\begin{array}{c}0-15 \\
15-30 \\
30-100 \\
0-15 \\
15-30 \\
30-100\end{array}$ & $\begin{array}{l}+33.7 \\
+19.6 \\
+11.7 \\
+23.9 \\
+16.9 \\
+14.9\end{array}$ & $\begin{array}{l}\text { Wheat to coarse } \\
\text { grasses }\end{array}$ & Poulton et al., 2003 \\
\hline Brown soil & $\begin{array}{l}\text { Broadbalk } \\
\text { Wilderness, } \\
\text { Rothamsted, Herts. }\end{array}$ & 1904-1964 & $\begin{array}{c}0-15 \\
15-30 \\
30-100 \\
0-15 \\
15-30 \\
30-100 \\
0-15 \\
15-30 \\
30-100\end{array}$ & $\begin{array}{l}+32.3 \\
+19.9 \\
+25.5 \\
+31.8 \\
+18.9 \\
+15.8 \\
+20.5 \\
+12.5 \\
+5.7\end{array}$ & $\begin{array}{l}\text { Wheat to mixed } \\
\text { deciduous woodland }\end{array}$ & Poulton et al., 2003 \\
\hline Brown soil & $\begin{array}{l}\text { Geescroft } \\
\text { Wilderness, } \\
\text { Rothamsted, Herts. }\end{array}$ & $1904 / 65-1999$ & $\begin{array}{c}0-15 \\
15-30 \\
30-100 \\
0-15 \\
15-30 \\
30-100\end{array}$ & $\begin{array}{l}+19.0 \\
+11.2 \\
+4.3 \\
+23.6 \\
+14.2 \\
+33.2 \\
\end{array}$ & $\begin{array}{l}\text { Mean of two soils } \\
\text { from wheat to oak } \\
\text { and ash woodland }\end{array}$ & Poulton et al., 2003 \\
\hline
\end{tabular}




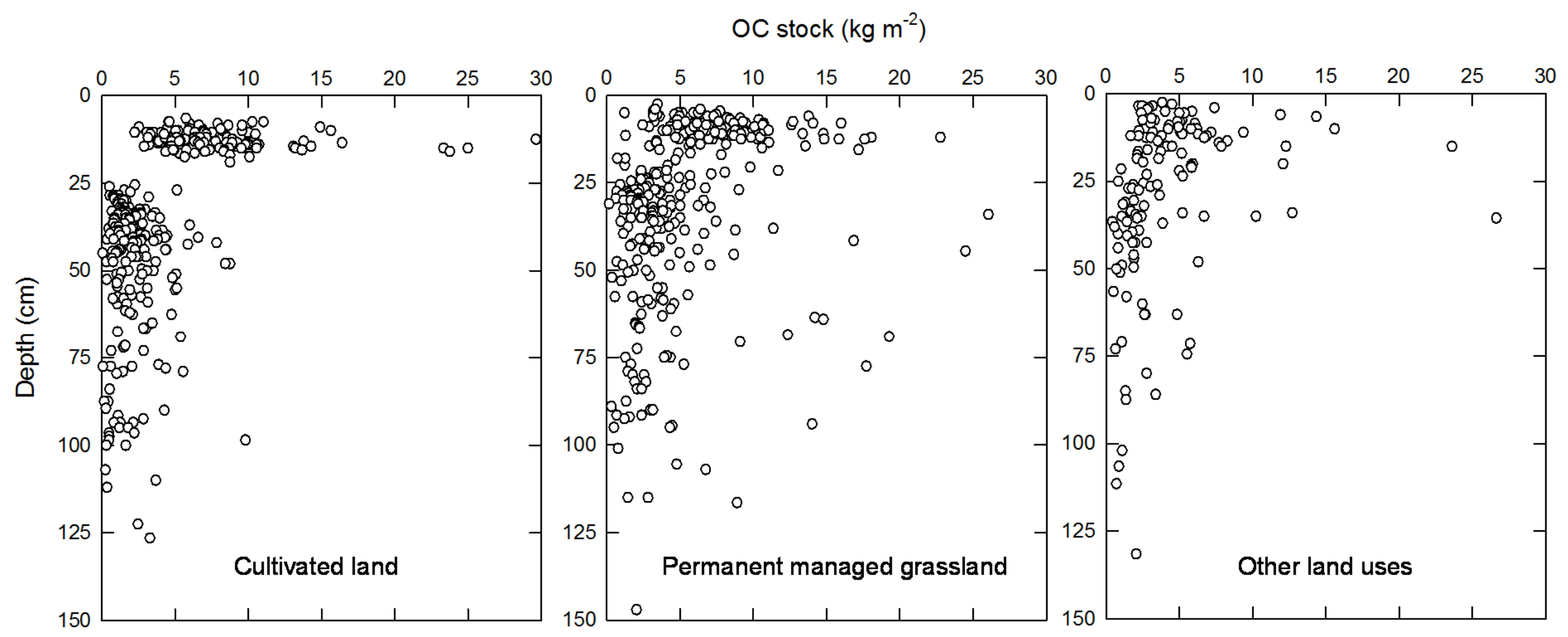

Figure 1 Depth distributions of soil organic C (OC) stocks per unit area from the Horizon Fundamentals dataset in LandIS for the main soil series in England and Wales calculated with Equation (1) and grouped by land use category. 